\title{
PENGARUH EFEKTIFITAS PEMBERIAN VITAMIN C DAN KAFEIN TERHADAP TINGKAT KELELAHAN OTOT SAAT MELAKUKAN AKTIVITAS FISIK MAHASISWA
}

\author{
Jhony Hendra ${ }^{1}$, Titis Wulandari ${ }^{2}$ \\ ${ }^{12}$ STKIP Muhammadiyah Muara Bungo, Pendidikan Jasmani Kesehatan dan \\ Rekreasi, Kota Bungo, Indonesia \\ Jhony.jho.hendra@gmail.com, Titiswulandari17@gmail.com
}

\begin{abstract}
Physical activity soccer can increase oxygen consumption in the body 10-20 times and 100-200 times in muscles. Increased use of oxygen results in the activity of radical production decreasing Hemoglobin $(\mathrm{Hb})$. The purpose of this study was to determine the effect of the effectiveness of vitamin $\mathrm{C}$ and caffeine on $\mathrm{Hb}$ levels on maximum physical activity. Aquasi-experimental study with sample testing was carried out at the Talang Pantai Soccer Field and $\mathrm{Hb}$ levels were tested at Puskesmas 2 Muara Bungo. This study measure $\mathrm{Hb}$ levels before and after consuming $90 \mathrm{mg}$ of vit $\mathrm{C}$ and $90 \mathrm{mg}$ of caffeine after playing soccer for 45 minutes. The results of statistical analysis ANOVA level $5 \%$. The results showed that there was an effect of $\mathrm{Hb}$ between the control group and the treatment group. The value of $\mathrm{F}_{h} 6.795$ with a sig of 0.13 , thehypothesis $\mathrm{H}_{1}$ is accepted if the sig < 0.05 because the sig value is $0.13>0.05$, so that the null hypothesis $\mathrm{H}_{0}$ is rejected, meaning that there is an effect of caffeine administration on $\mathrm{Hb}$ between the groups before caffeine administration and after caffeine administration. Meanwhile, the vitC test showed that there was an effect of $\mathrm{Hb}$ between the control group and the treatment group. This is evidenced by the value of $F_{h} 0.029$ with a sig 0.97 , the $\left(\mathrm{H}_{1}\right)$ is accept if the sig $<0.05$ because the sig $0.97>0.05 \mathrm{so}\left(\mathrm{H}^{0}\right)$ is rejected, meaning that there is an effect of giving vitamin $C$ and caffeine on muscle strength and endurance in students. Thus it can be concluded that, there is an effect of giving vitamin $\mathrm{C}$ and caffeine on muscle strength and muscle endurance when students do physical activity.
\end{abstract}

Keywords: Caffeine, Muscle Fatigue Level, Vitamin C

\begin{abstract}
Abstrak
Aktivitas fisik sepak bola dapat meningkatkan konsumsi oksigen dalam tubuh 10-20 kali dan 100200 kali lipat pada otot. Peningkatan penggunaan oksigen mengakibatkan aktifitas produksi radikal performance turunnya Haemoglobin $(\mathrm{Hb})$. Tujuan penelitian untuk mengetahui pengaruh efektifitas pemberian Vitamin $\mathrm{C}$ dan kafein terhadap kadar $\mathrm{Hb}$ pada aktifitas fisik maksimal. Penelitian eksperimental kuasi dengan pengujian sampel dilakukan di Lapangan Sepak Bola Talang Pantai dan dilakukan pengujian kadar haemoglobin yang dilakukan di Puskesmas 2 Muara Bungo. Penelitian ini mengukur kadar $\mathrm{Hb}$ sebelum dan sesudah mengkonsumsi vitamin $\mathrm{C}$ dosis $90 \mathrm{mg}$ dan kafein dosis $90 \mathrm{mg}$ setelah bermain sepak bola selama 45 menit. Hasil dianalisis statistik (ANOVA) taraf uji $5 \%$. Hasil menunjukkan bahwa terdapat pengaruh $\mathrm{Hb}$ antara kelompok kontrol dan kelompok perlakuan. Nilai $\mathrm{F}_{\text {hitung }}=6.795$ dengan nilai sig sebesar 0.13 , Hipotests $\left(\mathrm{H}_{1}\right)$ diterima jika nilai sig $<0.05$, karena nilai sig $0,13>0,05$, sehingga hipotesis nol $\left(\mathrm{H}_{0}\right)$ ditolak, berarti ada pengaruh pemberian kafein terhadap $\mathrm{Hb}$ antara kelompok sebelum pemberian kafein dan sesudah pemberian kafein. Sedangkan pada uji vitamin C menunjukkan bahwa terdapat pengaruh haemoglobin antara kelompok kontrol dan kelompok perlakuan. Hal ini dibuktikan dari nilai $F_{\text {hitung }}=0.029$ dengan nilai sig sebesar 0.97, Hipotests alternating $\left(\mathrm{H}_{1}\right)$ diterima jika nilai sig $<0.05$, karena nilai sig 0,97> 0,05 sehingga hipotesis nol $\left(\mathrm{H}_{0}\right)$ ditolak, berarti ada pengaruh pemberian viitamin $\mathrm{C}$ terhadap $\mathrm{Hb}$ antara kelompok sebelum pemberian vitamin $\mathrm{C}$ dan sesudah pemberian vitamin $\mathrm{C}$. Dengan demikian
\end{abstract}


JURNAL SPORTA SAINTIKA

P-ISSN 2505-5651

E-ISSN 2579-5910

dapat disimpulkan bahwa, ada pengaruh pemberian vitamin $\mathrm{C}$ dan kafein terhadap kekuatan otot dan daya tahan otot pada saat mahasiswa melakukan aktifitas fisik.

Kata kunci:. Kafein, Tingkat Kelelahan Otot, Vitamin C

\section{PENDAHULUAN}

Olahraga merupakan proses kegiatan yang memanfaatkan aktivitas fisik untuk menghasilkanperubahan holistik dalam kualitas individu, baik dalam hal fisik, mental, serta emosional (Marhaendra et al., 2016). Aktivitas fisik berat dapat meningkatkan konsumsi oksigen 100-200 kali lipat karena terjadi peningkatan metabolisme di dalam tubuh (Souza, 2006). Aktivitas fisik merupakan gerakan fisik yang dilakukan oleh otot tubuh dan sistem penunjangnya (Almatsier. 2003). Menurut (World Health Organization, 2010) aktivitas fisik adalah setiap gerakan tubuh yang dihasilkan oleh otot rangka yang memerlukan pengeluaran energi. Aktifitas fisik merupakan modulator dengan spectrum yang luas dan dapat terjadi pada tingkatfungsi pengaruh aktifitas fisik terhadap fungsi biologis dapat berupa pengaruh positif, yaitu memperbaikinamun pengaruh negatif yaitu menghambat atau merusak (Sianturi, 2011).

Menurut (Marpaung et al., 2019), aktivitas fisik yang tidak ada (kurangnya aktivitas fisik) merupakan faktor resiko independen untuk penyakit kronis. Aktivitas fisik merupakan faktor resiko independen untuk penyakit kronis, dan secara keseluruhan diperkirakan menyebabkan kematian secara global (World Health Organization, 2010). Aktivitas fisik maksimal dapat memicu terjadinya ketidak seimbangan antara produksi radikal bebas dan sistem pertahanan antioksidan tubuh, yang dikenal sebagai stres oksidatif (Harahap, 2008). Akibat salah beraktivitas rata-rata orang sekarang melakukan segala sesuatu yang tanpa disadari telah mencederai badan atau tubuh. Termasuk cidera badan akibat menanggung stres fisik berlebihan. Hal ini dikarenakan adanya peningkatan konsumsi oksigen terutama pada otot yang paling terbebani (paling aktif) yaitu mencapai 100 kali norma (Helianti \& Hairrudin, 2009). Terkait dengan aktifitas fisik dapat berhubungan dengan tingkat kelelahan dan kekuatan serta ketahanan tubuh seseorang, dimana keduanya menggunakan latihan beban untuk membentuk otot. Kekuatan dibentuk oleh latihan beban yang digunakan dalam tubuh yang normal dan ketahanan otot dibangun dengan latihan secara rutin untuk mempertahankan otot.

Menurut (UTAMA, 2010) secara teoritis, kafein yang merupakan komponen utama kopi memang memiliki efek terhadap otot manusia elalui mekanisme utilisasi lemak menjadi energi dan peningkatan kadar kalsium sel otot, sehingga kafein dapat meningkatkan performa otot dan menghambat terjadinya kelelahan otot. Sedangkan vitamin $C$ berfungsi untuk meningkatkan sistem kekebalan tubuh, serta vitamin C merupakan sumber nutrisi tambahan sebelum dan sesudah aktivitas fisik memiliki pengaruh yang besar pada kerusakan otot dan recovery otot (Buckley, 2010). 
JURNAL SPORTA SAINTIKA

P-ISSN 2505-5651

E-ISSN 2579-5910

Berdasarkan penjelasan di atas, terdapat keterkaitan antara kafein dan vitamin C terhadap performa otot manusia dan menghambat terjadinya kelelahan pada otot serta menambah nutrisi bagi otot sebelum melakukan aktifitas fisik. Dengan demikian kafein dan vitamin C memberikan dampak yang efektif terhadap peningkatan performa manusia saat melakukan aktifitas fisik. Berdasarkan hal tersebut, penelitan ini dilakukan bertujuan untuk mengetahui pengaruh efektifitas pemberian vitamin C dan kafein terhadap kadar haemoglobin pada aktifitas fisik (kelelahan otot) maksimal pada mahasiswa.

\section{METODELOGI PENELITIAN}

Secara umum rancangan penelitian ini adalah uji eksperimen dengan rancangan penelitian Eksperimen-Kuasi. Penelitian eksperimental kuasi adalah penelitian dilakukan eksperimen yang penempatan unit terkecil eksperimen kedalam kelompok eksperimen dan kontrol, tidak dilakukan dengan acak.

Metode penelitian eksperimen semu merupakan pengembangan dari true experimental design. Quasi experiment design ini mempunyai kelas kontrol tetapi tidak berfungsi sepenuhnya untuk mengontrol vaiabel-variabel luar yang mempengaruhi pelaksanaan eksperimen (Sugiyono, 2011). Teknik pengumpulan data menggunakan one group pretest-posttest design. one group pretest-posttest design adalah kegiatan penelitian yang memberikan tes awal (pretest) sebelum diberikan perlakuan, setelah diberikan perlakuan barulah memberikan tes akhir (posttest) (Arikunto, 2010).

Analisis data harus melalui uji prasyarat analisis yang meliputi; uji normalitas, uji homogenitas dan uji hipotesis dengan menggunakan aplikasi SPSS 16.0. Subjek penelitian mahasiswa STKIP Muhammadiyah Muara Bungo, populasi penelitian ini yaitu mahasiswa STKIP Muhammadiyah Muara Bungo yang berjenis kelamin laki-laki berjumlah 134 orang. Pengambilan sampel dengan cara purposive sampling yang digunakan dalam penelitian ini memiliki kriteria sampel penelitian dengan usia 18-21 tahun, dengan berat badan minimal $50 \mathrm{~kg}$ dan berat badan maksimal $65 \mathrm{~kg}$. Sampel 22 orang dibagi dalam 2 kelompok yaitu kelompok diberikan vitamin $\mathrm{C}$ dengan dosis 90mg dan kelompok diberikan kafein dengan dosis $90 \mathrm{mg}$.

Kegiatan penelitian ini dilakukan di Lapangan Sepak Bola Talang Pantai dan pengujian sampel yaitu kadar haemoglobin yang dilakukan di Puskesmas 2 Muara Bungo. Penelitian ini mengukur kadar haemoglobin sebelum dan sesudah mengkonsumsi vitamin $\mathrm{C}$ dengan dosis $90 \mathrm{mg}$ dan kafein dengan dosis $90 \mathrm{mg}$ setelah bermain sepak bola selama 45 menit. Data yang diperoleh berupa kadar hemoglobin.

Penelitian ini akan dianalisis tingkat kelelahan otot setelah pemberian vitamin $\mathrm{C}$ dan kafein sportasaintika.ppj.unp.ac.id 
JURNAL SPORTA SAINTIKA

P-ISSN 2505-5651

E-ISSN 2579-5910

sebelum aktivitas fisik maksimal. Data dianalisis secara statistik dengan Analisis Varian (ANOVA) taraf uji $5 \%$. Hipotesis penelitian ini adalah apakah ada pengaruh pemberian kafein dan vitamin $\mathrm{C}$ terhadap kelelahan otot saat melakukan aktifitas fisik (sepak bola).

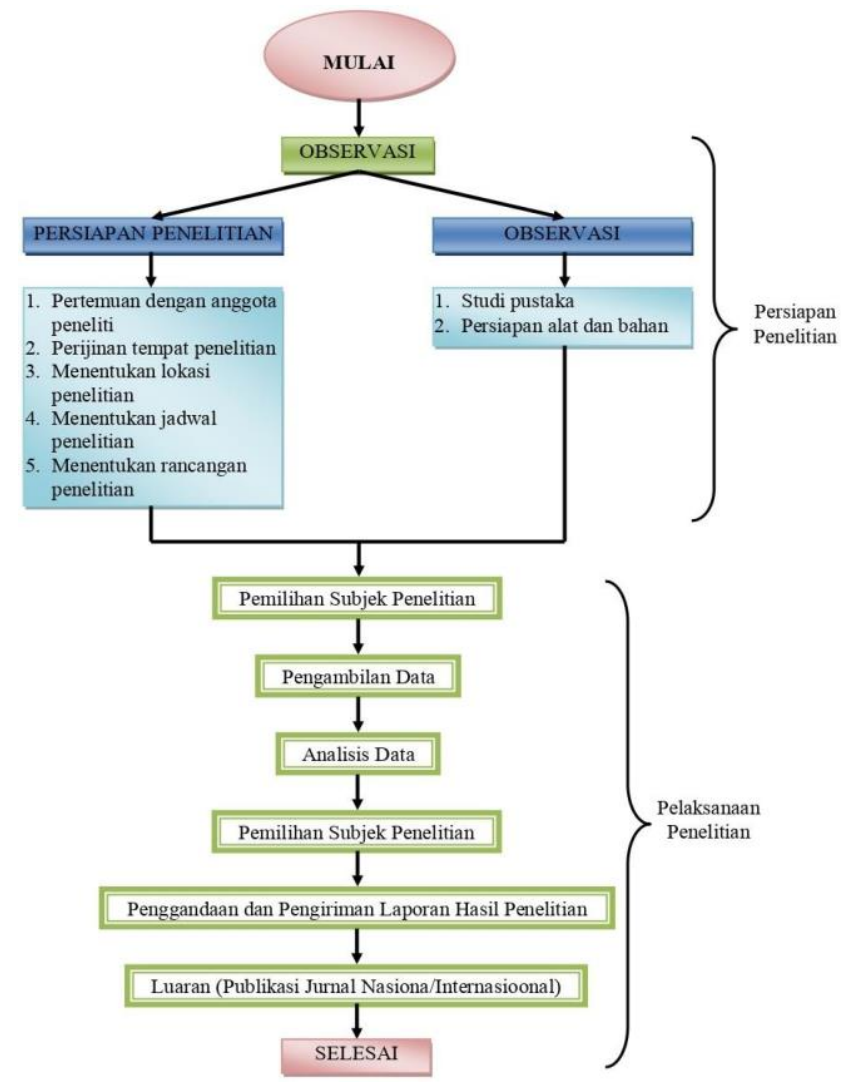

Gambar 1. Metode Penelitian

\section{HASIL PENELITIAN}

\section{A. Analisa deskriptif Hasil Penelitian}

Berdasarkan hasil penelitian ini dilakukan untuk mengetahui pengaruh pemberian kafein dan vitamin C terhadap kelelahan otot dalam tubuh akibat melakukan aktivitas fisik maksimal dalam melakukan olahraga sepak bola pada mahasiswa STKIP MB. Sebanyak 22 mahaiswa dibagi menjadi dua kelompok yaitu kelompok kontrol, kelompok diberikan vitamin C dengan dosis 90mg dan kelompok diberikan kafein dengan dosis $90 \mathrm{mg}$ dan kemudian dilakukan pengujian Haemoglobin. Berikut adalah data hasil pengujian $\mathrm{Hb}$ mahasiswa sebelum diberikan perlakuan kafein pada Tabel 1 dan Tabel 2 data hasil pengujian $\mathrm{Hb}$ mahasiswa sesudah diberikan perlakuan kafein .

Tabel 1. Data hasil uji $\mathrm{Hb}$ dan tekanan darah sebelum diberikan perlakuan kafein 
JURNAL SPORTA SAINTIKA

P-ISSN 2505-5651

E-ISSN 2579-5910

\begin{tabular}{|c|l|c|}
\hline No & \multicolumn{1}{|c|}{ Mahasiswa } & Hasil $\mathrm{Hb}$ \\
\hline 1 & Roki Andrian & 13,6 \\
\hline 2 & Fikri Aldip E & 13,8 \\
\hline 3 & Saydil Akbar & 13,2 \\
\hline 4 & Ade Gusyanda & 13,8 \\
\hline 5 & M. Idris & 13 \\
\hline 6 & Five Handika & 13,6 \\
\hline 7 & Gian Rahmat & 14 \\
\hline 8 & Riki mandala & 13,4 \\
\hline 9 & M. Ali & 13 \\
\hline 10 & Muhammad yadi S & 13,2 \\
\hline 11 & Juanda Agus & 13,4 \\
\hline
\end{tabular}

Tabel 2. Data hasil uji $\mathrm{Hb}$ dan tekanan darah sesudah diberikan perlakuan VitaminC

\begin{tabular}{|c|l|c|}
\hline No & \multicolumn{1}{|c|}{ Mahasiswa } & Hasil $\mathrm{Hb}$ \\
\hline 1 & Roki Andrian & 13,6 \\
\hline 2 & Fikri Aldip E & 13,5 \\
\hline 3 & Saydil Akbar & 13,2 \\
\hline 4 & Ade Gusyanda & 13,8 \\
\hline 5 & M. Idris & 13,2 \\
\hline 6 & Five Handika & 13,4 \\
\hline 7 & Gian Rahmat & 14,1 \\
\hline 8 & Riki mandala & 13,7 \\
\hline 9 & M. Ali & 13,3 \\
\hline 10 & Muhammad yadi S & 13,1 \\
\hline 11 & Juanda Agus & 13,4 \\
\hline
\end{tabular}

\section{B. Hasil Uji Normalitas}

Data yang diperoleh Haemoglobin sebelum dilakukan analisis dta, dilakukan uji normalitas data menggunakan uji normalitas Kolmogorov-smirnov, data normal jika nilai signifikan $>0,05$. Data berdistribusi normal kemudian dilakukan uji Data yang berdistribusi normal dilakukan uji parametrik, sedangkan data yang berdistribusi tidak normal dilakukan uji non parametrik. Data diuji dengan uji one way pada data berdistribusi normal. Jika Anda biasanya tidak menggunakan uji kruskal wallis kemudian dilakukan uji anova. uji Normalitas data ditentukan dengan menggunakan metode Kolmogorov-Smirnov pada Tabel 3 berikut.

Tabel 3. Hasil Uji Normalitas Hb sebelum dan sesudah pemberian kafein

\begin{tabular}{|l|l|}
\hline & Sebelum perlakuan \\
\hline
\end{tabular}


JURNAL SPORTA SAINTIKA

P-ISSN 2505-5651

E-ISSN 2579-5910

\begin{tabular}{|c|c|c|}
\hline \multicolumn{2}{|l|}{$\mathrm{N}$} & 11 \\
\hline \multirow{2}{*}{$\begin{array}{l}\text { Normal } \\
\text { Parameters }\end{array}$} & Mean & 13.45 \\
\hline & $\begin{array}{l}\text { Std. } \\
\text { Deviation }\end{array}$ & .336 \\
\hline \multirow{3}{*}{$\begin{array}{l}\text { Most } \\
\text { Extreme } \\
\text { Differences }\end{array}$} & Absolute & .139 \\
\hline & Positive & .139 \\
\hline & Negative & -.122 \\
\hline \multicolumn{2}{|l|}{ Test Statistic } & .139 \\
\hline Asymp. Sig. (2-tailed) & & $.200^{\circ}$ \\
\hline \multicolumn{3}{|c|}{ a. Test distribution is Normal. } \\
\hline \multicolumn{3}{|c|}{ b. Calculated from data. } \\
\hline c. Lilliefors Significanc & ction. & \\
\hline
\end{tabular}

Dari hasil uji data dengan kolmogorov-smirnov didapatkan data terdistribusi normal $(P>0,05)$ baik pada kelompok post-test kontrol dan perlakuan pemberian kafein adalah 0,20.

Tabel 4. Hasil Uji Normalitas Hb sebelum dan sesudah pemberian Vitamin C

\begin{tabular}{|c|c|c|}
\hline \multirow{2}{*}{\multicolumn{2}{|c|}{$\mathrm{N}$}} & Sebelum perlakuan \\
\hline & & 11 \\
\hline \multirow{2}{*}{$\begin{array}{l}\text { Normal } \\
\text { Parameters }{ }^{a, b}\end{array}$} & Mean & 13.4182 \\
\hline & Std. Deviation & .32502 \\
\hline \multirow{3}{*}{$\begin{array}{l}\text { Most } \\
\text { Extreme } \\
\text { Differences }\end{array}$} & Absolute & .167 \\
\hline & Positive & .113 \\
\hline & Negative & -.167 \\
\hline \multicolumn{2}{|l|}{ Test Statistic } & .167 \\
\hline \multicolumn{2}{|l|}{ Asymp. Sig. (2-tailed) } & $.200^{c}$ \\
\hline \multicolumn{3}{|c|}{ a. Test distribution is Normal. } \\
\hline \multicolumn{3}{|c|}{ b. Calculated from data. } \\
\hline c. Lilliefors Significance & tion. & \\
\hline
\end{tabular}

Dari hasil uji data dengan kolmogorov-smirnov didapatkan data terdistribusi normal $(P>0,05)$ baik pada kelompok post-test kontrol, post-test perlakuan pemberian vitamin $C$ adalah 0,20.

\section{B. Hasil Uji Homogenitas}

Uji homogenitas variabel data menggunakan uji homogenitas, data penelitian ini diuji parametrik sedang data yang berdistribusi tidak normal diuji dengan uji non parametrik, dengan selanjutnya pengujian dilakukan untuk mengetahui apakah datanya homogen atau tidak, data dikatakan homogen jika sig ( $p>0,05$ ). Uji homogenitas dan uji yang digunakan untuk mengetahui data haemoglobin pada kelompok perlakuan dan kelompok kontrol. Hasilnya Menunjukan data homogen $(p>0,05)$, terlihat pada Tabel 5 dan tabel 6 . 
JURNAL SPORTA SAINTIKA

P-ISSN 2505-5651

E-ISSN 2579-5910

Tabel 5. Uji Homogenitas $\mathrm{Hb}$ sebelum dan sesudah pemberian kafein

Test of Homogeneity of Variances

Nilai

\begin{tabular}{|c|c|c|c|}
\hline Levene Statistic & df1 & df2 & Sig. \\
\hline .357 & 1 & 20 & .557 \\
\hline
\end{tabular}

Tabel 6. Uji Homogenitas $\mathrm{Hb}$ sebelum dan sesudah pemberian vitamin $\mathrm{C}$

\begin{tabular}{|c|c|c|c|}
\hline \multicolumn{4}{|c|}{ Test of Homogeneity of Variances } \\
\hline \multicolumn{4}{|l|}{ Nilai } \\
\hline Levene Statistic & df1 & df2 & Sig. \\
\hline .004 & 1 & 19 & .953 \\
\hline
\end{tabular}

\section{Uji Hipotesis}

Uji hipotesis pada penelitian untuk mengetahui ada pengaruh pemberian kafein dan vitamin $\mathrm{C}$ diuji hipotesis dengan menggunakan anava. Pada penelitian ini menunjukkan hasil hemoglobin sig 0.30. Hipotesis yang digunakan dalam penelitian ini adalah sebagai berikut.

Ho: tidak ada pengaruh pemberian kafein terhadap kelelahan otot mahasiswa STKIP MB $\mathrm{H} 1$ : ada pengaruh pemberian kafein terhadap kelelahan otot mahasiswa STKIP MB

Berikut adalah tabel perhitungan uji hipotesis dengan Anava.

Tabel 7. Hasil Uji Anava Hb sebelum dan sesudah pemberian kafein

\begin{tabular}{|c|l|c|c|r|r|}
\hline \multicolumn{2}{|c|}{ Group Statistics } \\
\hline \multirow{2}{*}{ Nilai } & Kelas & N & Mean & Std. Deviation & \multicolumn{2}{c|}{ Std. Error Mean } \\
\cline { 2 - 6 } & Sebelum & 11 & 13.45 & .336 & .101 \\
\hline & Sesudah & 11 & 13.48 & .299 & .090 \\
\hline
\end{tabular}

\begin{tabular}{|l|rr|r|r|r|r|}
\hline \multicolumn{7}{|c|}{ ANOVA } \\
\hline Nilai & \multicolumn{1}{|l|}{$\begin{array}{l}\text { Sum of } \\
\text { Squares }\end{array}$} & Df & $\begin{array}{l}\text { Mean } \\
\text { Square }\end{array}$ & F & Sig &, 135 \\
\hline $\begin{array}{l}\text { Between } \\
\text { Groups }\end{array}$ & 1,087 & 8 &, 136 & 6,795 & \\
\hline $\begin{array}{l}\text { Within } \\
\text { Groups }\end{array}$ &, 040 & 2 &, 020 & & \\
\hline \multicolumn{1}{|c|}{ Total } & 1,127 & 10 & & & \\
\hline
\end{tabular}

Hasil penelitian menunjukkan bahwa terdapat pengaruh haemoglobin antara kelompok kontrol dan kelompok perlakuan. Hal ini dibuktikan dari nilai $F_{\text {hitung }}=6.795$ dengan nilai sig sebesar 0.13 , Hipotests alternating (h1) diterima jika nilai sig $<0.05$, karena nilai sig 0,13>0,05 sehingga hipotesis 
JURNAL SPORTA SAINTIKA

P-ISSN 2505-5651

E-ISSN 2579-5910

nol ( $\mathrm{H} 0)$ ditolak, berarti ada pengaruh pemberian kafein terhadap haemoglobin antara kelompok sebelum pemberian kafein dan sesudah pemberian kafein.

Uji hipotesis pada penelitian untuk mengetahui ada pengaruh pemberian vitamin $\mathrm{C}$ diuji hipotesis dengan menggunakan ano'va. Hipotesis yang digunakan dalam penelitian ini adalah sebagai berikut.

Ho: tidak ada pengaruh pemberian vitamin $C$ terhadap kelelahan otot mahasiswa STKIP MB

$\mathrm{H} 1$ : Ada pengaruh pemberian vitamin Cterhadap kelelahan otot mahasiswa STKIP MB

Berikut adalah tabel perhitungan uji hipotesis dengan Anava.

Tabel 8. Hasil analisi uji anova

\begin{tabular}{|l|l|c|c|r|r|}
\hline \multicolumn{2}{|c|}{ Group Statistics } \\
\hline & S. & & & Std. Deviation & Std. Error Mean \\
\hline \multirow{2}{*}{ B.Perlakuan } & B.Perlakuan & 11 & 13.42 & .325 & .098 \\
\cline { 2 - 6 } & S.Perlakuan & 11 & 13.45 & .324 & .098 \\
\hline
\end{tabular}

\begin{tabular}{|l|rr|r|r|r|r|}
\hline \multicolumn{7}{|c|}{ ANOVA } \\
\hline Nilai & $\begin{array}{l}\text { Sum of } \\
\text { Squares }\end{array}$ & Df & $\begin{array}{l}\text { Mean } \\
\text { Square }\end{array}$ & F & Sig \\
\hline $\begin{array}{l}\text { Between } \\
\text { Groups }\end{array}$ & .006 & 2 & .003 & .029 & .972 \\
\hline $\begin{array}{l}\text { Within } \\
\text { Groups }\end{array}$ & 2.101 & 19 & .111 & & \\
\hline Total & 2.108 & 21 & & & \\
\hline
\end{tabular}

Hasil penelitian menunjukkan bahwa terdapat pengaruh haemoglobin antara kelompok kontrol dan kelompok perlakuan. Hal ini dibuktikan dari nilai $F_{\text {hitung }}=0.029$ dengan nilai sig sebesar 0.97 , Hipotests alternating (h1) diterima jika nilai sig $<0.05$, karena nilai sig 0,97>0,05 sehingga hipotesis nol $(\mathrm{HO})$ ditolak, berarti ada pengaruh pemberian viitamin $\mathrm{C}$ terhadap haemoglobin antara kelompok sebelum pemberian kafein dan sesudah pemberian vitamin $\mathrm{C}$.

\section{PEMBAHASAN}

Sebuah studi menganalisis perkembangan obesitas tergantung pada aktivitas fisik adalah Aerobik Center Longitudinal Study (ACLS) yang dilakukan oleh Klinik Cooper, Texas(Reiner et al., 2013). Pria sehat berusia antara 22 dan 55 tahun pada awal dan lima tahun kemudian, tingkat aktivitas fisik keseharian berhubungan terhadap kenaikan berat badan sehingga mempengaruhi kondisi Hb (Di Pietro et al., 2004). Menurut (YusufAri Mashuri, Zara Offia Sweetry, 2020) Kelelahan 
JURNAL SPORTA SAINTIKA

P-ISSN 2505-5651

E-ISSN 2579-5910

kerja atau aktifitas fisik merupakan penurunan efisiensi dan ketahanan fisik manusia untuk melakukan pekerjaan, sehingga tingkat kelelahan yang dirasakan oleh pekerja dapat menyebabkan penurunan produktivitas. Aktivitas fisik telah diakui secara luas sebagai salah satu penentu utama yang meningkatkan kesehatan psikofisiologis positif pada individu (Roychowdhury, 2020). Aktivitas fisik berhubungan dengan kelelahan otot, yang dapat timbul akibat kontraksi otot yang kuat dan lama saat melakukan aktifitas fisik (Indriana, 2010). Olahraga adalah aktivitas fisik yang dapat membantu mengoptimalkan tubuh perkembangan melalui gerakan yang disadari dengan otot (Ainur Rasyid, 2019). Sepak bola merupakan salah satu olahraga yang memiliki tinggi power karena dalam olahraga ini ada 150-250 gerakan seperti menangkap, menggiring, melompat, mengoper, menendang, dan berlari dengan cepat (Chan et al., 2016).

Hasil penelitian menunjukkan ada pengaruh haemoglobin, antara kelompok kontrol dan perlakuan berpengaruh terhadap haemoglobin setelah melakukan aktifitas fisik dalam olahraga sepak bola. Bahwa dimana pemberian kafein dan vitamin C memberikan signifikan terhadap perubahan haemoglobin pada masing-masing kelompok sampel. Sampel dengan pemberian sebelum dan sesudah mengkonsumsi vitamin $\mathrm{C}$ dengan dosis $90 \mathrm{mg}$ dan kafein dengan dosis $90 \mathrm{mg}$ setelah bermain sepak bola selama 45 menit. Terdapat rata-rata sebelum pemberian kafein 13.45 dan sesudah 13.48 sedangkan sebelum pemberian vitamin C 13.42 serta sesudah pemberian vitamin $C$ adalah 13.45. hal ini baik pemberian kafein dan vitamin $C$ haemoglobin dapat menyebabkan kelelahan otot yang mengakibatkan terganggunya homeostasis. Penumpukan asam laktat menyebabkan kelelahan otot yang mengakibatkan terganggunya homeostasis habisnya sumber energi (Wahyu \& Saputro, 2016). Vitamin C dapat mempengaruhi dalam mengurangi stress oksidatif, sebanyak 10 jurnal membahas efek vitamin $C$ terhadap stress oksidatif tubuh (Makmun \& Rusli, 2020).

Menurut (Fitnesstest \& Test, 2015) Indeks persepsi kelelahan seorang atlet adalah terhadap tes daya tahan paru jantung, sebanyak 13 atlet terdiri dari beberapa skala kelelahan (RPE) yaitu skala 11 (ringan) berjumlah 1 orang (7,7\%), skala 13 (sedang) berjumlah 4 orang (30,8\%). Kelelahan otot adalah kegiatan akrifitas berat yang dilakukan seseorang secara maksimal yaitu latihan lari sprint, dan kelelahan itu sudah terjadi hanya dalam durasi 30 detik. Energi otot menurun sebesar $70 \%$ pada keadaan tersebut dan cadangan glikogen menurun sebesar $30 \%$ serta energi menurun sebesar 40-50\% (Wahyu \& Saputro, 2016). indeks kelelahan $(p<0,05)$. Penurunan kadar asam laktat terjadi recovery aktif dan recovery gabungan $(p<0,05)$, sedangkan kelompok massase tidak terjadi penurunan kadar asam laktat yang berarti $(p>0,05)$. (Rubbi Kurniawan, 2018)

Berdasarkan hasil uji korelasi untuk melihat pengaruh kafein terhadap kekuatan otot atlet 
JURNAL SPORTA SAINTIKA

P-ISSN 2505-5651

E-ISSN 2579-5910

sepak bola di SSB PERSISAC Kota Semarang berdasarkan kelompok perlakuan dan kelompok kontrol didapatkan hasil adalah ada pengaruh terhadap kekuatan otot atlet sepak bola (Nandatama et al., 2017). Kelelahan otot pada waktu berolahraga dapat disebabkan dari berbagai hal, diantaranya: menipisnya cadangan energy yang berasal dari ATP, kreatin fosfat, dan glikogen; akumulasi laktat dalam otot; gangguan homeostasis(Ainur Rasyid, 2019). Menurut (Nersyanti et al., 2006) kafein mempunyai fungsi sebagai stimulan dalam produksi energi dalam tubuh yang dapat mencegah kelelahan otot saat melakukan aktivitas fisik. Kafein merupakan komponen utama kopi, memiliki efek positif pada otot manusia melalui mekanisme yang mengubah lemak menjadi energi dan meningkatkan kadar kalsium sel otot, memungkinkan kafein memperbaiki kinerja otot sekaligus mengurangi kelelahan otot (Utama, 2010) .

Dari hasil penelitian sebelumnya ergogenik kafein meningkatkan peforma atlet, terutama untuk meningkatkan ketahanan aerobik dan meningkatkan kemampuan repetisi pada latihan otot (Hodgson et al., 2013). Sedangkan pada penelitian ini dapat dinyatakan bahwa pemberian vitamin C dan kafein dapat memberikan sumbangan yang positif terhadap kekuatan otot dan daya tahan otot dapat meningkat saat mahasiswa melakukan aktivitas fisik. Pemberian vitamin $\mathrm{C}$ dan kafein ini merupakan salah satu upaya untuk mengatasi kelelahan otot mahasiswa dalam melakukan aktivitas fisik. Hal ini berarti, dengan pemberian vitamin $C$ dan kafein dengan dosis yang sesuai dapat mengurangi kelelahan otot saat melakukan aktivitas fisik. Pemberian vitamin $\mathrm{C}$ dan kafein diperlukan kontrol yang baik dari dosen dan mahasiswa, apabila tidak dilakukan dengan sesuai akan berdampak terhadap mahasiswa itu sendiri pada saat melakukan aktivitas fisik.

\section{KESIMPULAN}

Berdasarkan hasil penelitian dapat disimpulkan bahwa ada pengaruh pemberian vitamin $\mathrm{C}$ dengan dosis $90 \mathrm{mg}$ dan kelompok diberikan kafein dengan dosis $90 \mathrm{mg}$ terhadap kelelahan otot, pada hasil pengujian haemoglobin terdapat rata-rata sebelum diberikan kafein sebesar 13.45 dan rata-rata sesudah diberikan kafein sebesar 13.48 , sedangkan rata-rata sebelum diberikan vitamin $\mathrm{C}$ sebesar 13.42 dan rata-rata sesudah diberikan vitamin C sebesar 13.45. Dengan demikian berarti, pemberian vitamin $\mathrm{C}$ dan kafein terhadap kekuatan otot dan daya tahan otot dapat meningkat saat mahasiswa melakukan aktivitas fisik.

\section{DAFTAR PUSTAKA}

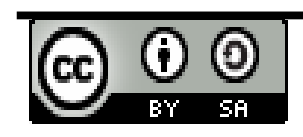
sportasaintika.ppj.unp.ac.id 
P-ISSN 2505-5651

E-ISSN 2579-5910

Almatsier, S. 2003. Prinsip Dasar IImu Gizi. Jakarta: Gramedia Pustaka Utama.

Arikunto, S. (2010). Prosedur Penelitian Suatu Pendekatan Praktik. Jakarta: Rineka Cipta.

Ainur Rasyid, N. A. (2019). Pengaruh pemulihan aktif joggingterhadap penurunan asam laktat pada olahraga bulutangkis. 10-18.

Buckley, J. T. (2010). Supplementation with a whey protein hydrolysate enhances recovery of muscle force-generating capacity following eccentric exercise. Journal of Science and Medicine Sport, 178-181.

Chan, H. C. K., Fong, D. T. P., Lee, J. W. Y., Yau, Q. K. C., Yung, P. S. H., \& Chan, K. M. (2016). Power and endurance in Hong Kong professional football players. Asia-Pacific Journal of Sports Medicine, Arthroscopy, Rehabilitation and Technology, 5, 1-5. https://doi.org/10.1016/j.asmart.2016.05.001

Dewi, K. I., \& Wirjatmadi, R. B. (2018). Hubungan Kecukupan Vitamin C Dan Zat Besi Dengan Kebugaran Jasmani Atlet Pencak Ipsi Lamongan. Media Gizi Indonesia, 12(2), 134. https://doi.org/10.20473/mgi.v12i2.134-140

Di Pietro, L., Dziura, J., \& Blair, S. N. (2004). Estimated change in physical activity level (PAL) and prediction of 5-year weight change in men: The Aerobics Center Longitudinal Study. International Journal of Obesity, 28(12), 1541-1547. https://doi.org/10.1038/sj.ijo.0802821

Fitnesstest, M., \& Test, R. (2015). Persepsi atlet terhadap tingkat kelelahan pada multistage fitness test dan yo-yo intermittend recovery test. Xvi(2).

Halimah, N., Rosidi, A., \& SU, Y. N. (2014). Hubungan Konsumsi Vitamin C Dengan Kesegaran Jasmani Pada Atlet Sepakbola di Pusat Pendidikan dan Latihan Olahraga Pelajar Jawa Tengah. Jurnal Gizi, 3(2), 17-24.

Harahap, N. S. (2008). Pengaruh Aktifitas Fisik Maksimal Terhadap Jumlah Leukosit dan Hitung Jenis Leukosit pada Mencit (Mus Musculus L) Jantan. USU E-Repository @, 1-24.

Helianti, D., \& Hairrudin. (2009). Efek Protektif Propolis Dalam Mencegah Stres Oksidatif Akibat Aktivitas Fisik Berat (Swimming Stress) "Propolis" Protective Effect to Prevent Oxidative Stress Caused by Strenous Physical Activity (Swimming Stress). Jurnal IImu Dasar, 10(2), 207-211.

Hodgson, A. B., Randell, R. K., \& Jeukendrup, A. E. (2013). The Metabolic and Performance Effects of Caffeine Compared to Coffee during Endurance Exercise. PLOS ONE, 8(4).

https://doi.org/10.1371/journal.pone.0059561

Indriana, T. (2010). The influence of muscle fatigue on work carefulness. Indriana, T. (n.d.). No Title., $7(3), 49-52$.

Makmun, A., \& Rusli, F. I. P. (2020). Pengaruh vitamin c terhadap sistem imun tubuh untuk Universitas Muslim Indonesia, Makassar Corresponding author e-mail : 
JURNAL SPORTA SAINTIKA

P-ISSN 2505-5651

E-ISSN 2579-5910

armanto.makmun@umi.ac.id. Molucca Medika, 12(2), 60-64.

Marhaendra, Y. A., Basyar, E., \& Adrianto, A. (2016). Pengukuran Tekanan Darah. Jurnal Kedokteran Diponedoro, 5(4), 1930-1936.

Marpaung, D. R., Samosir, A. S., Purba, S. M., \& Fitri, K. (2019). Efek Pemberian Minuman Energi Yang Mengandung Kafein Dan Taurin Terhadap Daya Tahan Dan Kadar Asam Laktat Saat Melakukan Aktifitas Fisik Pada Mahasiswa Ilmu Keolahragaan 2016. Sains Olahraga : Jurnal IImiah IImu Keolahragaan, 2(2), 1. https://doi.org/10.24114/so.v2i2.11366

Nandatama, S., Rosidi, A., \& Gizi, Y. U. (2017). Minuman Kopi (Coffea) terhadap kekuatan otot dan ketahanan otot atlet sepak bola usia remaja di SSB PERSISAC. Jurnal.Unimus.Ac.Id, 6(1), 2934. https://jurnal.unimus.ac.id/index.php/jgizi/article/view/2701

Nersyanti, F., Kimia, D., Matematika, F., Ilmu, D. A. N., \& Alam, P. (2006). Spektrofotometri Derivatif Ultraviolet.

Putu Ayu Widiastuti, M.M Wara Kushartanti, B. . I. K. (2009). 17682-35018-1-SM.pdf (Vol. 6, pp. 1320).

Reiner, M., Niermann, C., Jekauc, D., \& Woll, A. (2013). Long-term health benefits of physical activity A systematic review of longitudinal studies. BMC Public Health, 13(1), 1-9.

https://doi.org/10.1186/1471-2458-13-813

Rosidi, A. (2000). Hubungan status gizi, status kesehatan dan aktivitas fisik dengan kesegaran jasmani atlet PSIS Semarang.

Roychowdhury, D. (2020). Using physical activity to enhance health outcomes across the life span. Journal of Functional Morphology and Kinesiology, 5(1). https://doi.org/10.3390/jfmk5010002

Rubbi Kurniawan, A. E. (2018). Optimalisasi Teknik Recovery untuk Pemain Sepakbola Rubbi. 3(2), 172-177.

Sianturi, Y. S. (2011). Dampak Desentralisasi Fiskal Terhadap Ketimpangan pendapatan Antar Wilayah (Studi Kasus Kabupaten/Kota Provinsi Sumatera Utara). 21-30.

Sugiyono. (2011). Metode Penelitian Kuantitatif, Kualitatif dan R\&D. Bandung: Afabeta.

Utama, Y. (2010). Pengaruh Pemberian Kopi Terhadap Kelelahan Otot. Skripsi, 15-19.

Wahyu, B., \& Saputro, A. (2016). Perbandingan pemberian vitamin c dan kafein Eksperimen Pada Tikus Stain Wistar ( Rattus norvegicus ). 1-72.

World Health Organization. (2010). Global recommendations on physical activity for health. World Health Organization, 1-116.

YusufAri Mashuri, Zara Offia Sweetry, I. S. (2020). ISSN 2089-4503 (cetak) 338. Jurnal IImiah IImu Kesehatan Vol.8, No.3, 2020, Hal 338-345, 8(3), 338-345. 
JURNAL SPORTA SAINTIKA

P-ISSN 2505-5651

E-ISSN 2579-5910 